\title{
A Study of the Relationship between Educational Environment of Madarsas and Their Students' Satisfaction in Kanpur City
}

Dr. Sarfaraz Ahmad*

Assistant Professor (Department of B.Ed.), Halim Muslim P.G. College, Kanpur, India

DOI: $10.36348 /$ sjhss.2021.v06i02.001

| Received: 20.01.2021 | Accepted: 01.02.2021 | Published: 04.02.2021

*Corresponding author: Dr. Sarfaraz Ahmad

\section{Abstract}

India has been growing (Making future of the nation) in terms of the schools. Madarsas is also a type of school. If the environment of Madarsas is better and favourable for students, certainly the student of that school will also develop. Madarsas' educational environment might have some important effect on students' education and vocational success. The main objective of the present research is to know the relation of educational environment of Madarsas and their Students' Satisfaction in Kanpur City. For this, 400 students are selected from Kanpur - Aided and Private Madarsas by random sampling method. The result found that the educational environment of Madarsas in Kanpur City has a meaningful relationship with the satisfaction of their students.

Keywords: Madarsa, Educational Environment and Students' Satisfaction.

Copyright ( 12021 The Author(s): This is an open-access article distributed under the terms of the Creative Commons Attribution 4.0 International License (CC BY-NC 4.0) which permits unrestricted use, distribution, and reproduction in any medium for non-commercial use provided the original author and source are credited.

\section{INTRODUCTION}

"The destiny of India is now being shaped in her classrooms. This, we believe, is no more rhetoric."

-Kothari Education Commission (1964-66)

Education is the process of development by which one adopts oneself gradually in various ways from one's psychological, social and spiritual environment from infancy to maturity. Environment plays dominant role in influencing and shaping the behavior and thoughts of students. Environment has different agencies. School is one of them. In present era different types of school are available in India to provide quality education to students. Madarsa is a type of school.

Madarsas have been providing traditional education in India. During the medieval period Madarsas had been the centers of higher learning. Madarsas were granted Jagirs (land \& Village) by the kings and land lords for their maintenance. These institutions used to receive other financial grants as well. Madarsas were the only source of education for those students who could not afford to pay a handsome amount for education as they charge no fee and provide free boarding and lodging to their students.
At present, there are more than 40,000 Madarsas in India. Government, N.G.O.s' provide financial assistance to Madarsas. The scheme of financial assistance for modernization of Madarsas' education is being implemented to encourage traditional institution like Madarsas and Maktabs to introduce Science, Mathematics, Social-Science, Hindi, and English in their curriculum. Under this scheme centper-cent assistance is given to such institutions for appointment of qualified teachers for teaching the new subjects to be introduced.

School environment help the students to develop conduct which is socially, emotionally, educationally, approved. Ming \& Rebecca [1], results revealed that school environment is associated with students' perception directly and indirectly. The environment of school helps development of students. Thus educational environment of Madarsas can affect their students' developments also. Educational environment of Madarsas can either impede or support learning. Gabriel, Bonnie \& Sidney [2]; results were consistent with the idea that a careful attention needs to be given to the socio-emotional and educational environment of middle schools, particularly for young adolescents preoccupied with issues of self identity. 


\section{Need and Importance of the Study}

The 'World Trade Centre' tragedy in the US has brought the ancient Madarsas into limelight and they were labeled as breeding ground of Islamic terrorism, Madarsas's environment was questioned, suddenly found them under harsh scrutiny. In India, anti-Islamic group and media started a campaign against the Madarsas as breeding grounds for "terrorism".

In February 2008, an "Anti-terrorism Conference", organized by Darul - Uloom in Deoband, Uttar Pradesh, denounced all forms of terrorism, declaring that "Islam condemns all kinds of oppression, violence and terrorism". The conference also denounced widespread attempts of blaming the practicing Muslims for terrorist incidents.

The incident of attack on police station at Sopor in Azamgarh was brought in focus of Madarsas by print media on June 1st, 2012. The environment of Madrsas was suspected. It was claimed that Madarsas are the centre of terrorism and anti-national activities. The example related to such activities was attack on Police Station at Sopor in Azamgarh. But Human-Right Organization gave clean chit to the Madarsas' students and said they were innocent.

India has been growing (Making future of the nation) in terms of the schools. Madarsas is also a type of school. If the atmosphere of Madarsas is better and favourable for students, certainly the student of that school will also develop. Madarsas' educational environment might have some important effect on students' education and vocational success.

Students' satisfaction with the school environment plays a great impact in their learning. Ferreira \& Chainho [3]; results revealed that school satisfaction had a positive effect on the special needs of students and school organization board. It would keep them update and help them sail through teenage smoothly. Dissatisfaction with Madarsas can be a major cause for undesirable behavior in students. Keeping in mind the importance of Madrasas' environment, the proposed study will be concentrated on Madarsas Environment as a deciding factor of students' development. Madarsas' educational environment might have some important aspects of students' education and vocational success. The proposed study focuses on the educational environment of Madarsas in Kanpur city and how far the students are satisfied with the Madarsas environment.

Statement of the Study: "A study of the relationship between Educational Environment of Madarsas and their Students' Satisfaction in Kanpur City”.

\section{Operational definition of Variables in the study Madarsas}

The word Madarsa is derived from the Arabic word 'Daras' which means to deliver speech. Generally, after primary education during medieval period education was imparted through speech or lecture, therefore the institutions where teaching was carried out by lecture method were designated as Madarsas. Madarsas in the medieval period were mostly located either in state capital or in big cities. At present, there are more than 40,000 Madarsas in India. Government \& N.G.O.s provides financial assistance to Madarsas. The scheme of financial assistance for modernization of Madarsas' education is being implemented to encourage traditional institution like Madarsas \& Maktab and also by introducing science, Mathematics, Social-Science, Hindi and English in their curriculum. Under this scheme cent-per-cent assistance is given to such institutions for appointment of qualified teachers for teaching the new subject to be introduced.

\section{Educational Environment of the Madarsas}

The word environment is a comprehensive word. It includes within itself the world 'environment'. The elements around the student constitute an 'environment'. It embraces the social, physical and emotional activities of school. All these activities combined together and constitute educational environment of school, which plays an important role in student's life.

Educational environment of Madarsas has significant contribution in all round development of their students. In Madarsas, the students interact with the teachers, administrator, and other students and to other persons working there. If seen, all these factors are helpful in making the attitude in among students for the educational environment of Madarsa.

\section{Satisfaction of the Madarsas}

School Satisfaction refers to a student's subjective cognitive appraisal of their school life. School satisfaction is perhaps best understood in the larger context of wellness indicators. Madarsa is also the type of school. Satisfaction of Madarsas means therefore implies the fulfillment of student's need and expectations.

\section{OBJECTIVES}

The present study is to conduct to attain the following objectives-

1. To study the Educational environment of Madrsas of Kanpur city.

2. To study the students' satisfaction of the Madarsas.

3. To study the relation between educational environment of aided Madarsas and their malestudents' satisfaction with the environment of Madarsas in Kanpur City.

4. To study the relation between educational environment of aided Madarsas and their female- 
students' satisfaction with the environment of Madarsas in Kanpur City.

5. To study the relation between educational environment of aided Madarsas and their students' satisfaction with the environment of Madarsas in Kanpur City.

6. To study the relation between educational environment of private Madarsas and their malestudents' satisfaction with the environment of Madarsas in Kanpur City.

7. To study the relation between educational environment of private Madarsas and their femalestudents' satisfaction with the environment of Madarsas in Kanpur City.

8. To study the relation between educational environment of private Madarsas and their students' satisfaction with the environment of Madarsas in Kanpur City.

9. To study the relation between educational environment of Madarsas and their male-students' satisfaction with the environment of Madarsas in Kanpur City.

10. To study the relation between educational environment of Madarsas and their femalestudents' satisfaction with the environment of Madarsas in Kanpur City.

11. To study the relation between educational environment of Madarsas and their students' satisfaction with the environment of Madarsas in Kanpur City.

Hypothesis: The following null hypothesis (Ho :) are also formulated-

1. There will be no significant relation between educational environment of aided Madarsas and their male-students' satisfaction with the environment of Madarsas in Kanpur City.

2. There will be no significant relation between educational environment of aided Madarsas and their female-students' satisfaction with the environment of Madarsas in Kanpur City.

3. There will be no significant relation between educational environment of aided Madarsas and their students' satisfaction with the environment of Madarsas in Kanpur City.

4. There will be no significant relation between educational environment of private Madarsas and their male-students' satisfaction with the environment of Madarsas in Kanpur City.
5. There will be no significant relation between educational environment of private Madarsas and their female-students' satisfaction with the environment of Madarsas in Kanpur City.

6. There will be no significant relation between educational environment of private Madarsas and their students' satisfaction with the environment of Madarsas in Kanpur City.

7. There will be no significant relation between educational environment of Madarsas and their male-students' satisfaction with the environment of Madarsas in Kanpur City.

8. There will be no significant relation between educational environment of Madarsas and their female-students' satisfaction with the environment of Madarsas in Kanpur City.

9. There will be no significant relation between educational environment of Madarsas and their students' satisfaction with the environment of Madarsas in Kanpur City.

Limations of the Study: This study is based on following limitations-

1. The area of the research of present study is confined to Kanpur City.

2. The study is confined only to Madarsas' students.

3. The study is confined only to educational environment of Madarsas.

4. The study is confined to satisfaction of the students of the Madarsas.

\section{RESEARCH METHODOLOGY}

Types of Research Method \& Technique - Survey technique is used in this present descriptive research.

Population - The students studying in Madarsas of Kanpur city constituted the population of the study.

Sample \& Sampling - A sample is composed of selected numbers of individuals, each of which is member of the total population.

The Random sampling technique is to be used for this present study. The study will be conducted on total 400 students of 20 Madarsas (07 Government Aided +13 Private) of Kanpur city. The selection of students will be done by random sampling using lottery method. The following table shows the numbers of students from different type of Madarsas.

Table-1

\begin{tabular}{|l|l|l|l|}
\hline Students Madarsas & Boys & Girls & Total \\
\hline Aided & 50 & 90 & 140 \\
\hline Private & 126 & 134 & 260 \\
\hline Total & 176 & 224 & $\mathbf{4 0 0}$ \\
\hline
\end{tabular}


Tools for Data Collection- Under the present research, Observation method, Interview and taking into consideration the objectives of the study, the following tools is used for the purpose of data collection:

\section{Educational Environment of Madarsas}

Self made standardized questionnaire is to measure educational environment of Madarsas. This questionnaire has 50 items. This is a three point scale "Yes", "No", and "Same Time". Marking for statement $2,0 \& 1$ respectively. Ready-reckoner given below serves as a quick guide-

\begin{tabular}{|l|l|}
\hline Raw Score & Categories \\
\hline Above 61 & High Level \\
\hline 39 to 60 & Average Level \\
\hline Below 39 & Low Level \\
\hline
\end{tabular}

\section{Satisfaction Inventory}

Sharma School Satisfaction Inventory (S.A.S.S.I.) constructed by Dr. (Mrs.) Meenakshi Sharma will be used. It is a standardized test. S.A.S.S.I. has 60 items. Ready-reckoner given below serves as a quick guide:

\begin{tabular}{|l|l|}
\hline Raw Score & Categories \\
\hline 92 or Above & Very Satisfied \\
\hline Between 76 to 91 & Satisfied \\
\hline Between 58 to 75 & Dissatisfied \\
\hline 57 to Below & Very Dissatisfied \\
\hline
\end{tabular}

Procedure: The tool is administered personally on the above - said population. Before administering the questionnaire, a rapport is established with these subjects and they are assured confidentiality of their responses. The filled-up questionnaires are then scored in the prescribed manner given in the respective manual and obtained data tabulated for statistical analysis.

Statistical Technique: In the present study the data is given the following treatment - Mean, S.D. \& "r" - test.

Analysis and Interpretation: The analyzed data are presented in Tables 1, 2 and 3.

Table-2: The Educational Environment of Madarsas in Kanpur City

\begin{tabular}{|l|l|l|l|l|l|}
\hline Educational Environment & Students & Mean & S.D. & Level & Category \\
\hline Aided Madarsas & Boys(50) & 88.96 & 3.232 & Above61 & High \\
\cline { 2 - 6 } & Girls(90) & 87.86 & 9.445 & Above61 & High \\
\cline { 2 - 6 } & Total(140) & 88.25 & 7.815 & Above61 & High \\
\hline \multirow{5}{*}{ Private Madarsas } & Boys(126) & 80.80 & 12.565 & Above61 & High \\
\cline { 2 - 6 } & Girls(134) & 86.97 & 6.677 & Above61 & High \\
\cline { 2 - 6 } & Total(260) & 83.98 & 10.423 & Above61 & High \\
\hline All Madarsas & Boys(176) & 83.12 & 11.371 & Above61 & High \\
\cline { 2 - 6 } & Girls(224) & 87.33 & 7.898 & Above61 & High \\
\cline { 2 - 6 } & Total(400) & 85.48 & 9.795 & Above61 & High \\
\hline
\end{tabular}

Interpretation: The value of Educational Environment of the students (Boys / Girls) studying in all types of Madarsas (Aided / Private) showed in Table-3 is above than 61. According to the students of Madarsas, the educational environment of Madarsas is good.

Table-3: The Students' Satisfaction with the environment of Madarsas in Kanpur City

\begin{tabular}{|l|l|l|l|l|l|}
\hline Educational Environment & Students & Mean & S.D. & Level & Category \\
\hline Aided Madarsas & Boys(50) & 154.86 & 6.961 & Above92 & Very Satisfied \\
\cline { 2 - 6 } & Girls(90) & 157 & 13.979 & Above92 & Very Satisfied \\
\cline { 2 - 6 } & Total(140) & 156.24 & 11.969 & Above92 & Very Satisfied \\
\hline \multirow{5}{*}{ Private Madarsas } & Boys(126) & 143.44 & 24.662 & Above92 & Very Satisfied \\
\cline { 2 - 6 } & Girls(134) & 153.4 & 13.664 & Above92 & Very Satisfied \\
\cline { 2 - 6 } & Total(260) & 148.57 & 20.353 & Above92 & Very Satisfied \\
\hline All Madarsas & Boys(176) & 146.69 & 21.787 & Above92 & Very Satisfied \\
\cline { 2 - 6 } & Girls(224) & 154.84 & 13.873 & Above92 & Very Satisfied \\
\cline { 2 - 6 } & Total(400) & 151.26 & 18.226 & Above92 & Very Satisfied \\
\hline
\end{tabular}

Interpretation: The value of Educational Environment of the students (Boys / Girls) studying in all types of Madarsas (Aided / Private) showed in Table-3 is more than 92. It indicates that the students of Madarsas are very satisfied with the environment of Madarsas. 
Sarfaraz Ahmad., Saudi J. Humanities SocSci, Feb, 2021; 6(2): 37-42

Table-4: Correlation between Educational Environment of Madarsas and Students' Satisfaction with the Environment of Madarsas in Kanpur City

\begin{tabular}{|c|c|c|c|c|c|c|}
\hline Madarsas & Students & Variables & Mean & S.D. & 'r' & Level of Significance \\
\hline \multirow[t]{6}{*}{ Aided } & \multirow[t]{2}{*}{ Boys } & Educational Environment & 88.96 & 3.232 & \multirow[t]{2}{*}{.189} & \multirow{2}{*}{$\begin{array}{l}\text { Significance at } 0.01 \text { Level } \\
(>0.115)\end{array}$} \\
\hline & & Satisfaction & 15.86 & 6.961 & & \\
\hline & \multirow[t]{2}{*}{ Girls } & Educational Environment & 87.86 & 9.445 & \multirow[t]{2}{*}{.631} & \multirow[t]{2}{*}{ Significance at 0.01 Level $(>0.115)$} \\
\hline & & Satisfaction & 157 & 13.979 & & \\
\hline & \multirow[t]{2}{*}{ Total } & Educational Environment & 88.25 & 7.815 & \multirow[t]{2}{*}{.581} & \multirow{2}{*}{$\begin{array}{l}\text { Significance at } 0.01 \text { Level } \\
(>0.115)\end{array}$} \\
\hline & & Satisfaction & 156.24 & 11.969 & & \\
\hline \multirow[t]{6}{*}{ Private } & \multirow[t]{2}{*}{ Boys } & Educational Environment & 80.8 & 12.565 & \multirow[t]{2}{*}{.816} & \multirow{2}{*}{$\begin{array}{l}\text { Significance at } 0.01 \text { Level } \\
(>0.115)\end{array}$} \\
\hline & & Satisfaction & 143.44 & 24.662 & & \\
\hline & \multirow[t]{2}{*}{ Girls } & Educational Environment & 86.97 & 6.677 & \multirow[t]{2}{*}{.502} & \multirow{2}{*}{$\begin{array}{l}\text { Significance at } 0.01 \text { Level } \\
(>0.115)\end{array}$} \\
\hline & & Satisfaction & 153.4 & 13.664 & & \\
\hline & \multirow[t]{2}{*}{ Total } & Educational Environment & 83.98 & 10.423 & \multirow[t]{2}{*}{.759} & \multirow[t]{2}{*}{ Significance at 0.01 Level $(>0.115)$} \\
\hline & & Satisfaction & 148.57 & 20.353 & & \\
\hline \multirow[t]{6}{*}{ All } & \multirow[t]{2}{*}{ Boys } & Educational Environment & 83.12 & 11.371 & \multirow[t]{2}{*}{.811} & \multirow[t]{2}{*}{ Significance at 0.01 Level $(>0.115)$} \\
\hline & & Satisfaction & 146.69 & 21.787 & & \\
\hline & \multirow[t]{2}{*}{ Girls } & Educational Environment & 87.33 & 7.898 & \multirow[t]{2}{*}{.560} & \multirow[t]{2}{*}{ Significance at 0.01 Level $(>0.115)$} \\
\hline & & Satisfaction & 154.84 & 13.873 & & \\
\hline & \multirow[t]{2}{*}{ Total } & Educational Environment & 85.48 & 9.795 & \multirow[t]{2}{*}{.733} & \multirow[t]{2}{*}{ Significance at 0.01 Level $(>0.115)$} \\
\hline & & Satisfaction & 151.26 & 18.226 & & \\
\hline
\end{tabular}

The correlation between the educational environment and satisfaction of students (Boys / Girls) of all types of Madarsas (Aided / Private) was found to be above than the value of $0.01(>0.115)$. So null hypothesis Ho.: 1, Ho.: 2, Ho.: 3, Ho.: 4, Ho.: 5, Нo.:6, Ho.:7, Ho.:8 \& Ho.:9 are rejected.

\section{FINDINGS}

The following results were obtained in the present research-

1. There is significant relation between educational environment of aided Madarsas and their boy-students' satisfaction with the environment of Madarsas in Kanpur City.

2. There is significant relation between educational environment of aided Madarsas and their girl-students' satisfaction with the environment of Madarsas in Kanpur City.

3. There is significant relation between educational environment of aided Madarsas and their students' satisfaction with the environment of Madarsas in Kanpur City.

4. There is significant relation between educational environment of private Madarsas and their boy-students' satisfaction with the environment of Madarsas in Kanpur City.

5. There is significant relation between educational environment of private Madarsas and their Girl-students' satisfaction with the environment of Madarsas in Kanpur City.

6. There is significant relation between educational environment of private Madarsas and their students' satisfaction with the environment of Madarsas in Kanpur City.

7. There is significant relation between educational environment of Madarsas and their boy-students' satisfaction with the environment of Madarsas in Kanpur City.

8. There is significant relation between educational environment of Madarsas and their girl-students' satisfaction with the environment of Madarsas in Kanpur City.

9. There is significant relation between educational environment of Madarsas and their students' satisfaction with the environment of Madarsas in Kanpur City.

\section{CONCLUSION}

The above findings denote that the Madarsas' students are satisfied with the educational environment of madarsas of Kanpur city.

The main probable reason for the above results that the educational climate of Madarsas is favourable in Kanpur city, therefore the result is satisfactory.

In other perspective- During Survey, various details like educational detail of parents, their monthly income, and location of residence etc. were to be filled in the questionnaire. This information revealed many facts about the status of the family of students. Based on this information, it was found out that the social and economic level of the families of Madarsas' students is very low. Probably the educational climate of Madarsas is better than the family climate of students which led to the satisfaction of students with the educational climate of Madarsas.

Other probability is that the Madarsas' students must be coming in less contact with other students of different type of schools due to which they must not be having the information about the facilities 
provided by different school. This fact also led to their satisfaction with Madarsas' climate.

\section{RECOMMENDATIONS}

The following recommendation are given in the project-

1. All Madarsas should be registered.

2. Madaras modernization should be carried out as an integral part of national education policy.

3. Madarsas' administrator should be establishing an atmosphere of faith and credibility in education.

4. Madarsas' administrator should bring the transparent image of Madarsas in front of Government.

5. Government should develop positive attitude towards Madarsas and bring the muslim to the main stream along with their identity.

6. Government should be dragged attention towards the condition of Madarsas.

7. Government should launch a specific program to develop proper physical infrastructure in these Madarsas.

8. People of Muslim community are suggested for a regular financial support similar to other community schools for these registered Madarsas.

9. An integral curriculum should be immediately developed for these Madarsas to balance the subjects of both streams. Important subjects should be introduced with the joint effort of Muslim intellectual and educationist.

10. Study material should be prepared in Urdu medium.

(The present research is taken from the minor research project of researcher. It is funded by the C.S.J.M. University, Kanpur.)

\section{REFERENCE}

1. Ming-Te, W., \& Rebecca, H. (2010). Adolescents Perceptions of School Environment in Middle School. American Educational Research Journal, 47, 633-662.

2. Gabriel, P. K., Bonnie, J. L., \& Sidney, J. B. (2001). Psychological Vulnerability to depression and problem behavior student perceptions of school socio-emotional climate. Journal of School Psychology, Elseveier U.S.A. Memphis University. 39(7), 141-159.

3. Simões, C., Matos, M. G., Tomé, G., Ferreira, M., \& Chaínho, H. (2010). School satisfaction and academic achievement: the effect of school and internal assets as moderators of this relation in adolescents with special needs. Procedia-Social and Behavioral Sciences, 9, 1177-1181. 